\title{
MAFIC AND ULTRAMAFIC IGNEOUS ROCKS OF THE RAISDUODDAR- HALTI AREA IN THE FINNISH-NORWEGIAN CALEDONIDES. PETROGRAPHY, MINERALOGY AND GEOCHEMISTRY
}

\author{
PEKKA SIPILÄ
}

\begin{abstract}
SIPILÄ, PEKKA, 1991: Mafic and ultramafic igneous rocks of the RaisduoddarHalti area in the Finnish-Norwegian caledonides. Petrography, mineralogy and geochemistry. Bull. Geol. Soc. Finland 63, Part 1, 15-24.

The mafic and ultramafic rocks in the Raisduoddar-Halti area constitute a shallow horizontal allochthonous plate in the highest tectono-stratigraphic position of the Finnish Caledonides. They are located close to the boundary of the lower part of the Vaddas Nappe in the Upper Allochthon and the Kalak Nappe Complex in the Middle Allochthon. The mafic and ultramafic rocks in the area are Ridnitsohkka gabbro sills in the east and dunite-troctolite-olivine gabbro cumulates at Raisduoddar-Halti. They are syngenetic and belong to the same nappe. The lower contact with the Nabar schists of the Kalak Nappe Complex on the cumulate side is distinctly tectonic and may continue as a tectonic contact in the sill area, too.

The gabbro sills, which are tholeiitic in chemical composition, are enriched in LREE and show a small positive Eu anomaly. Close to the cumulate the gabbro sills contain olivine.

The cumulate massif crystallized mainly as a closed system, as shown by the linear change in the composition of the rocks and minerals. The cumulates are intruded by coarse grained gabbro pegmatoids. The same pegmatoid magma gave rise to the metasomatic olivine gabbro with augite porphyroblasts between the cumulate massif and the sill area. Before last nappe movements the rocks of the cumulate massif were partly amphibolitized across the lithologic contacts and magmatic layering.

As suggested by the total lithologic composition and the mineral composition, the magmatism in the area contains evidence of at least two major magmatic events. First, tholeiitic gabbro sills intruded the acid schists. Then, the magma type having become more primitive the Raisduoddar-Halti cumulates fractionated.

A new U-Pb age of $434 \pm 4 \mathrm{Ma}$ on baddeleyite from Ridnitsohkka gabbro sills shows that the mafic and ultramafic rocks in the area can be correlated with the synorogenic Scandian mafic intrusive rocks in the Scandinavian Caledonides.
\end{abstract}

Key words: gabbros, sills, cumulates, chemical composition, electron probe data, caledonides, Paleozoic, RidnitsohkKa, Enontekiö, Finland.

Pekka Sipilä: Department of Geology, University of Turku, SF-20500 Turku, Finland. Present address: Geological Survey of Finland, SF-02150, Espoo, Finland.

\section{Introduction}

The Scandinavian Caledonides extend to Finland only within a small area in the northernmost parts of the country, between Sweden and Norway (Fig. 1, Index map). Detailed information about the geology of the Finnish Caledonides has been obtained only recently as a result of regional 

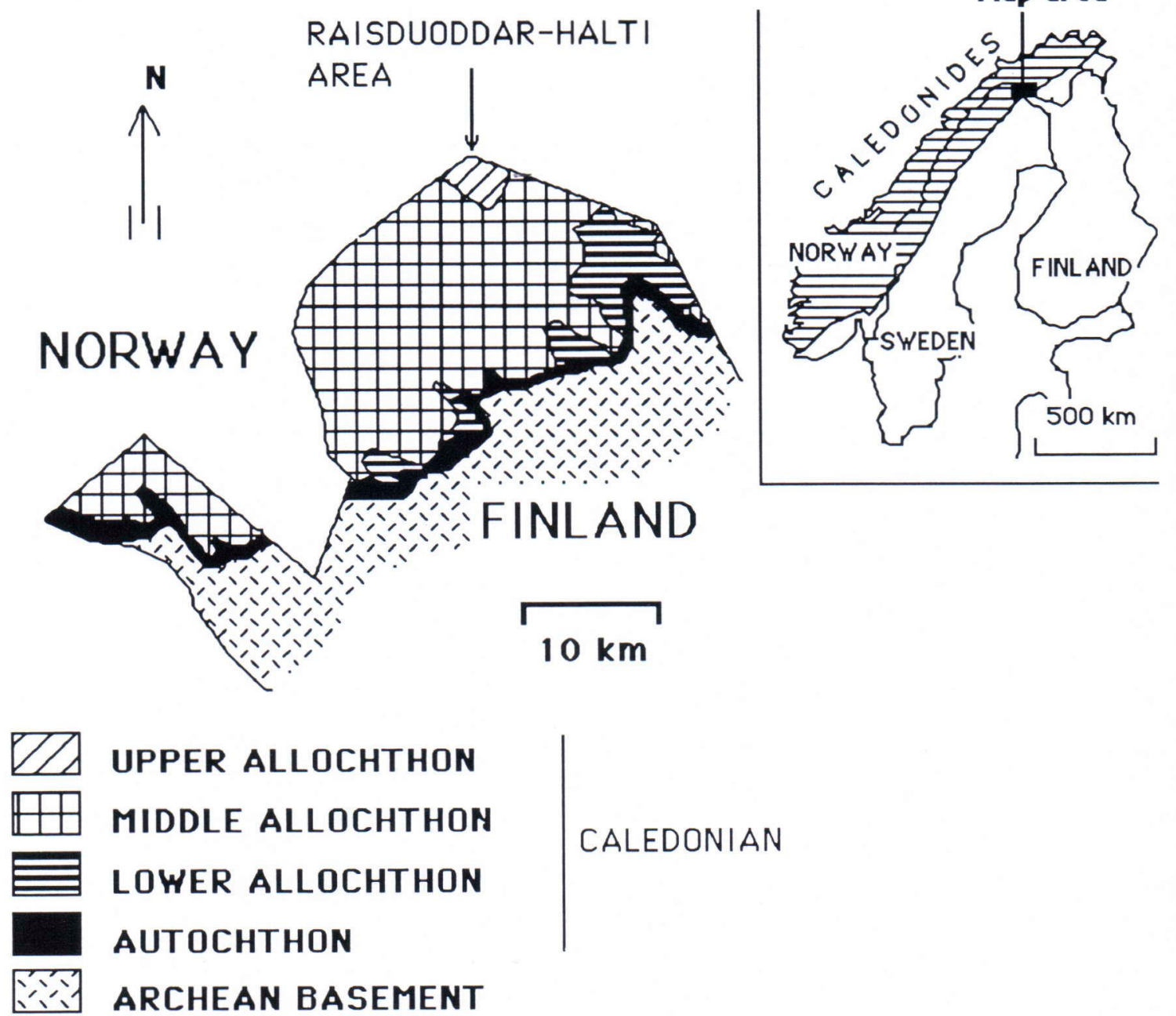

Fig. 1. The Caledonides in Finland. Modified from Lehtovaara 1986.

mapping undertaken there by geologists from the University of Turku. The mafic and ultramafic rocks in the area have been studied by Hausen (1941, 1942), Böe (1976), Lehtovaara and Sipilä (1987) and Sipilä (1987, 1988, 1989).

The greater part of the Finnish Caledonides belongs to the Kalak Nappe of the Middle Allochthon (Fig. 1). The autochthonous cover and the Lower Allochthon, which are exposed as a narrow rim in the southeastern margin of the Caledonian overthrust nappes, rest on the $\mathrm{Ar}$ - chaean basement. The ultramafic and mafic rocks in the Raisduoddar-Halti area are close to the boundary of the Lower Vaddas Nappe and Upper Kalak Nappe and they occupy the highest tectono-stratigraphic and topographic position in the Finnish Caledonides (Lehtovaara 1986, 1989). The position of the Raisduoddar-Halti is interesting tectonostratigraphically as it is located in the debated boundary zone between the Finnmarkian and Scandian phases of the Caledonian orogeny. The Finnish Caledonides have usually been 
considered to belong to the allochthons of the Finnmarkian phase (Zwaan and Roberts 1978). Since the nearest Scandian phase allochthon is only a few kilometers away, it has also been suggested that the rocks at Raisduoddar-Halti may belong to the lower parts of Scandian nappes (Lehtovaara 1984). Recent data on U-Pb ages from Ridnitsohkka gabbro sills (Vaasjoki et al., in prep.) show that the Scandian phase allochthons extend to Finland. The classification of the rocks into the orogenic phases in the northern Norway is, however, a controversial subject, and some researchers have questioned the existence of the Finnmarkian phase (Krill and Zwaan 1987).

The Raisduoddar-Halti Magmatic Complex occurs as a horizontal allochthonous sheet on the summits of the Raisduoddar-Halti and Ridnitsohkka fells on both sides of the FinnishNorwegian border (Fig. 2). The complex is composed of Ridnitsohkka gabbro sills (= dolerite dyke swarm by Böe, 1976) in the east and Raisduoddar-Halti dunite-troctolite-olivine gabbro cumulates. The rocks overlying the sheet have been eroded. The lower contact with the Nabar schists is distinctly tectonic on the side of the cumulates. The eastern margin of the sill area is surrounded by a agmatitic garnet-kyanite contact aureole approximately $500 \mathrm{~m}$ thick.

\section{Petrography}

\section{The Ridnitsohkka gabbro sills}

The eastern Ridnitsohkka sill area is about 2 $\mathrm{km}$ wide. It extends northward following the shape of the cumulate massif. The conformable garnet-sillimanite gneiss interlayers are up to fifty meters wide and dip invariably towards the cumulates. The frequency of the gneiss interlayers is highest farthest from the cumulate massif. In chemical composition, the gabbro sills are tholeiitic; they are enriched in LREE and show a small positive Eu anomaly. The main primary minerals are plagioclase, clinopyroxene and or- thopyroxene. Close to the cumulate massif, the gabbro sills contain olivine. In places, pyroxene is intensely uralitized and kelyphytic rims have developed between olivine and plagioclase. The modal composition of the gabbro sills is shown in Fig. 3. Olivine is nearly totally altered and it is represented by the alteration products in the mode. The gabbro sills show weakly developed layering close to the cumulate massif. There are no cooling contacts with the gneiss interlayers, rather they were partly melted.

\section{The Raisduoddar-Halti cumulate massif}

The cumulates at Raisduoddar-Halti are exposed within an area of about $14 \mathrm{~km}^{2}$. Furthermore, in the west there are three small satellites separated by erosion. The bulk of the massif is composed of dunite-troctolite-olivine gabbro cumulates. The troctolite and olivine gabbro exhibit distinct layering, which in the east is subvertical but in the northeast and west dip gently towards the centre of the massif. Synmagmatic breccia structures show that accumulation took place in a tectonically unsettled environment. The breccia matrix is heterogeneous, varying from pegmatoidal olivine gabbro to troctolitic dunite with small amounts of plagioclase. A breccia may contain both dunitic and anorthositic fragments, of which the largest measure several meters across. The brecciating material was often crystal mush, as demonstrated by the plagioclase laths oriented concordantly with the breccia fragments. The modal composition of the cumulate massif is shown in Fig. 3.

In the eastern part of the massif there is a coherent northwards tapering dunite tongue with narrow discontinuous troctolite and anorthosite interlayers and a few stratiform chromitite layers. In general, the dunite is massive in texture. Initially it was coarse-grained, but later the olivine grains were intensely mechanically granulated. Chrome spinel is a common accessory. At their thickest, the discontinuous chrome spirel layers measure $20 \mathrm{~cm}$. 


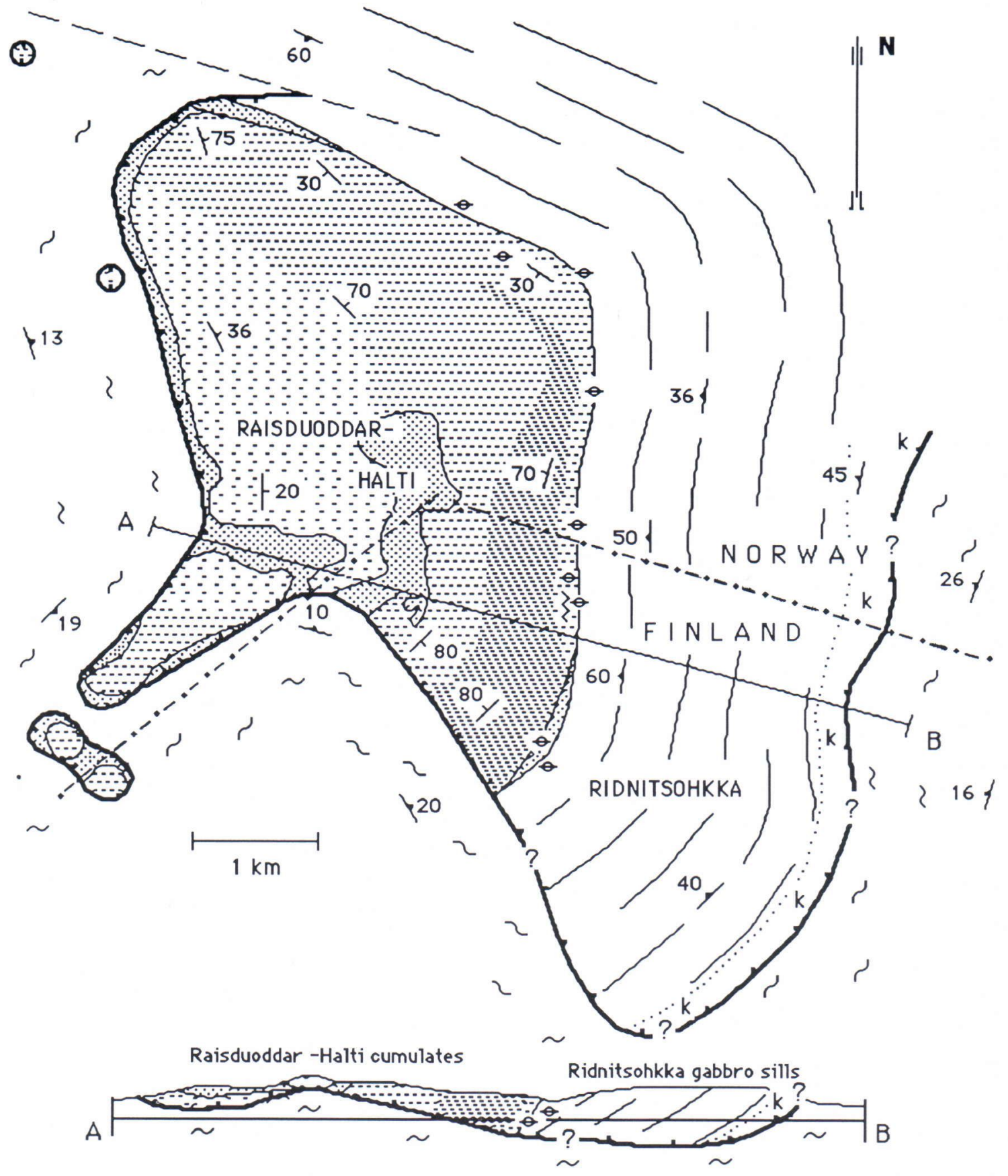

Raisduoddar-

Halti Cumulates

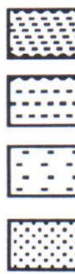

DUNITE

\section{TROCTOLITE}

$\therefore$ OLIVINE GABBRO AMPHIBOLE ROCK

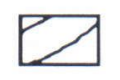

RIDNITSOHKKA GABBRO SILLS with Sill-Gar-gneiss interlayers

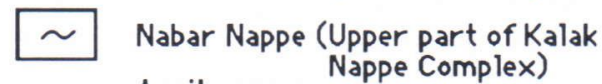

- Augite augen

k Kyanite

$\because$ Eastern boundary of Gabbro Sills

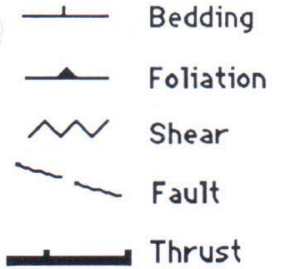

Fig. 2. Geological map of Raisduoddar-Halti and Ridnitsohkka areas. 


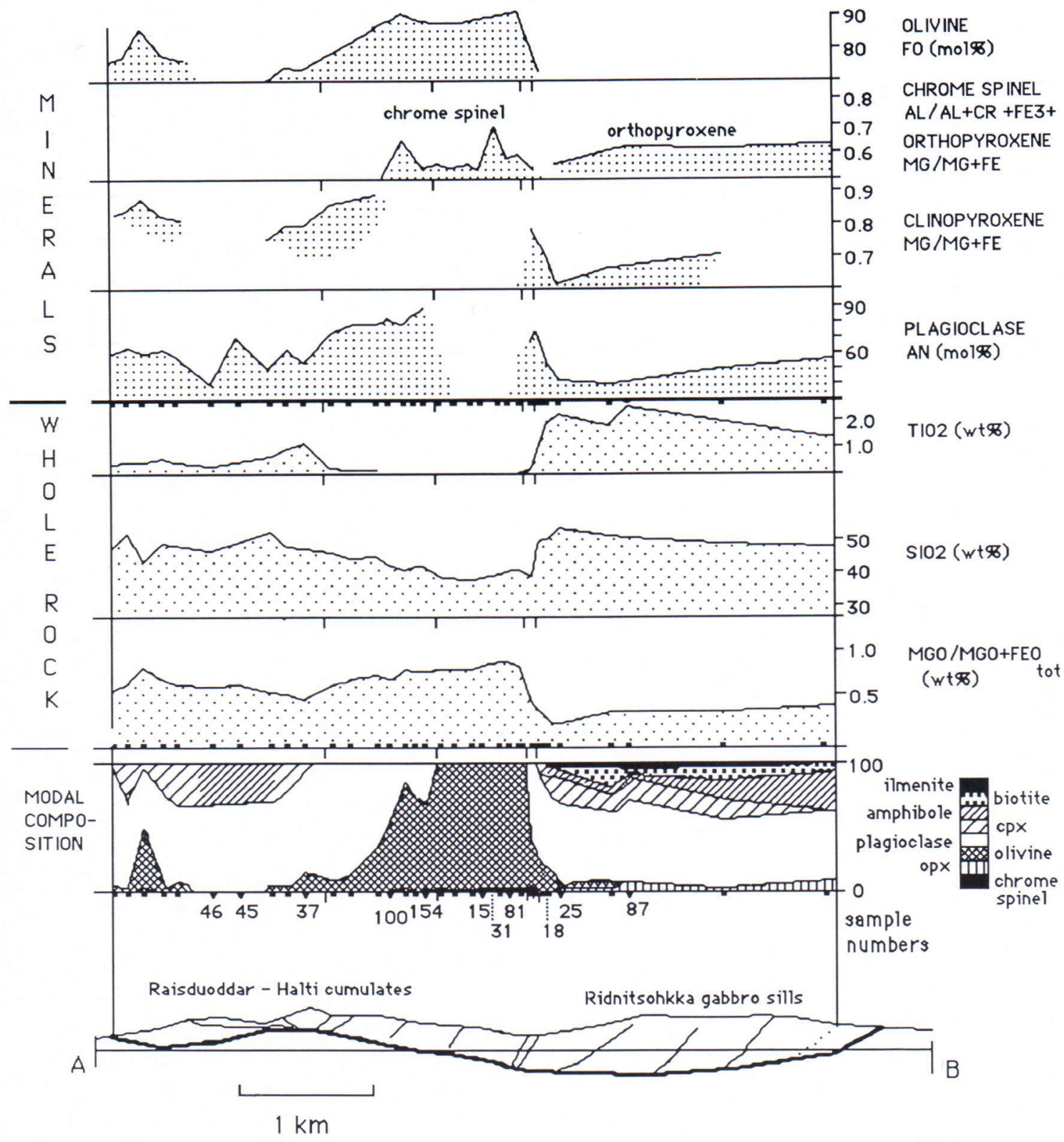

Fig. 3. Variation in chemical composition of minerals and rocks. Cross-section AB is shown in Fig. 2.

The predominant rock type at RaisduoddarHalti is distinctly layered troctolite, the layering being due to the modal variation in olivine and plagioclase abundances. The layers are discon- tinuous and vary from centimeters to several meters in thickness. In places, magmatic lineation is well developed. Granulation and the intense kelyphytic reaction between olivine and 
plagioclase have obliterated cumulus textures in many places (Sipilä 1988). The accessories are chrome spinel and augite.

With the increase in clinopyroxene abundance, the troctolite grades into olivine gabbro. Stratigraphically in the highest position, the olivine gabbro is usually massive in texture, although in the westernmost portions of the massif the olivine gabbro, too, shows modal layering.

The last differentiates are very coarse-grained gabbro pegmatoids. Their mineral composition is the same as that of the olivine gabbros.

The same pegmatoid magma generated a metasomatic gabbro with augite porphyroblasts between the sill area and the cumulates. This zone is devoid of intrusive gabbro pegmatoids. Porphyroblasts have grown not only in cumulate but also in olivine-bearing gabbro sills. In places the rock with augite porphyroblasts has undergone intense shearing and developed augen structures. Lehtovaara and Sipilä (1987) consider the zone between the cumulate massif and sill area as a possible overthrust surface. However, according to recent observations, this is not the case because shearing is intensive further within the sill area. Neither are the coarse gabbros with augite porphyroblasts restricted to this zone; they also occur as narrow concordant horizons in the cumulates.

In the central and western parts of the cumulate massif the plagioclase-bearing rocks are intensely amphibolitized. The amphibolitization cuts the layering and predates the nappe movements because foliation is intense only close to the overthrust surface. The amphibole rocks can be divided into two subtypes: amphibole-zoisite rocks and the more rare amphibole-chlorite rocks.

\section{Geochemistry of rocks and minerals}

The various rock types were analysed with respect to their main components and the trace ele- ments $\mathrm{Cr}$, $\mathrm{Co}$ and $\mathrm{Ni}$. The main components were analysed by XRF and AAS at the Department of Geology, University of Turku and the trace elements by XRF at the Technical Research Centre of Finland in Espoo. Mineral analyses were made at the laboratory of Material Sciences, Department of Physical Sciences, University of Turku using energy dispersive (EDS) technique.

Dozens of analyses were carried out, but only representative analyses are included in the tables $1-5$. Fig. 3 includes additionally all those analyses which are made along profile AB in Fig. 2.

The variation in the total composition of the rock types and in olivine, clinopyroxene, orthopyroxene and plagioclase compositions along profile $\mathrm{AB}$ in Fig. 2 is shown in Fig. 3. In the sill area the whole-rock $\mathrm{MgO} / \mathrm{MgO}+\mathrm{FeO}_{\text {tot }}$ decreases and $\mathrm{SiO}_{2}$ and $\mathrm{TiO}_{2}$ increase towards the contact with the cumulate. At the same time the anorthite content of the plagioclase and the $\mathrm{Mg} / \mathrm{Mg}+\mathrm{Fe}$ ratio in clinopyroxene and orthopyroxene decline. The parental magma of the gabbro sills was thus differentiated and its oldest parts are located farthest from the cumulate.

In the cumulate, the whole-rock $\mathrm{MgO} / \mathrm{MgO}+$ $\mathrm{FeO}_{\text {tot }}$ decreases and $\mathrm{SiO}_{2}$ increases from the eastern part of the dunite to the olivine gabbro on the summit of Raisduoddar-Halti; from there these elements behave in the opposite manner. The $\mathrm{TiO}_{2}$ abundance is very low in dunite and troctolite. It is highest in the olivine gabbro on the summit and declines towards the western contact of the complex. The forsterite content in olivine, the $\mathrm{Mg} / \mathrm{Mg}+\mathrm{Fe}$ ratio in clinopyroxene, the $\mathrm{Al} / \mathrm{Al}+\mathrm{Cr}+\mathrm{Fe}^{3+}$ ratio in chromite and anorthite content in plagioclase vary in harmony with the variation in the whole-rock $\mathrm{MgO} / \mathrm{MgO}+$ $\mathrm{FeO}_{\text {tot }}$. The variation in the chemical composition of the rocks and minerals in the cumulate together with the observations of layering demonstrate that, in the east, the stratigraphically lowermost rocks are against the sill area and that the uppermost rocks are on the southern summit of the Raisduoddar-Halti fell. 
Mafic and ultramafic igneous rocks of the Raisduoddar-Halti area in the . .

Table 1. Representative whole rock analyses of Raisduoddar-Halti and Ridnitsohkka areas.

\begin{tabular}{|c|c|c|c|c|c|c|c|c|}
\hline $\begin{array}{l}\text { Sample No.: } \\
\text { Location }\end{array}$ & $\begin{array}{c}15 \\
\mathrm{R}-\mathrm{H}\end{array}$ & $\begin{array}{l}100 \\
\mathrm{R}-\mathrm{H}\end{array}$ & $\begin{array}{c}37 \\
\text { R-H }\end{array}$ & $\begin{array}{c}31 \\
\mathrm{R}-\mathrm{H}\end{array}$ & $\begin{array}{c}18 \\
\text { R-H }\end{array}$ & $\begin{array}{c}45 \\
\text { R-H }\end{array}$ & $\begin{array}{l}87 \\
\mathrm{Ri}\end{array}$ & $\begin{array}{l}25 \\
\mathrm{Ri}\end{array}$ \\
\hline \multicolumn{9}{|c|}{ Major elements (wt\%) } \\
\hline $\mathrm{SiO}_{2}$ & 36.91 & 41.53 & 47.00 & 51.94 & 46.70 & 47.67 & 50.91 & 49.70 \\
\hline $\mathrm{TiO}_{2}$ & 0.02 & 0.15 & 1.14 & 0.52 & 0.46 & 0.26 & 2.17 & 1.47 \\
\hline $\mathrm{Al}_{2} \mathrm{O}_{3}$ & 0.22 & 16.84 & 18.79 & 19.32 & 18.80 & 21.49 & 18.06 & 17.21 \\
\hline $\mathrm{FeO}^{*}$ & 9.51 & 7.57 & 7.23 & 4.48 & 6.56 & 4.14 & 9.11 & 7.60 \\
\hline $\mathrm{MnO}$ & 0.13 & 0.10 & 0.09 & 0.09 & 0.11 & 0.08 & 0.17 & 0.15 \\
\hline $\mathrm{MgO}$ & 46.03 & 27.66 & 9.63 & 6.47 & 10.87 & 9.46 & 6.06 & 8.28 \\
\hline $\mathrm{CaO}$ & 0.28 & 6.10 & 11.46 & 12.29 & 10.10 & 12.37 & 8.13 & 10.15 \\
\hline $\mathrm{Na}_{2} \mathrm{O}$ & - & 0.63 & 3.14 & 3.81 & 3.19 & 2.74 & 3.92 & 3.84 \\
\hline $\mathrm{K}_{2} \mathrm{O}$ & 0.01 & 0.06 & - & 0.08 & 0.06 & - & 0.74 & 0.17 \\
\hline L.O.I. & 5.39 & 1.17 & 0.15 & 0.48 & 0.05 & 0.65 & 0.38 & 0.07 \\
\hline Total & 98.50 & 101.81 & 98.63 & 99.52 & 96.90 & 98.79 & 99.64 & 98.64 \\
\hline \multicolumn{9}{|c|}{ Trace elements (ppm) } \\
\hline $\mathrm{Cr}$ & 2910 & 1490 & 383 & 280 & 165 & 616 & 191 & 316 \\
\hline Co & 131 & 85 & 43 & 27 & 47 & 36 & 49 & 38 \\
\hline $\mathrm{Ni}$ & 2120 & 752 & 117 & 135 & 163 & 158 & 31 & 106 \\
\hline
\end{tabular}

$15=$ dunite, $100=$ troctolite, $37=$ olivine gabbro, $31=$ gabbro pegmatoid, $18=$ augite augen gabbro, $45=$ amphibole rock, $87=$ cpx-opx gabbro sill, $25=$ cpx-ol gabbro sill (ol is pseudomorphous). Location: $\mathrm{R}-\mathrm{H}=\mathrm{Raisduoddar-Halti,}$ $\mathrm{Ri}=$ Ridnitsohkka. For additional information on specific sample locations, see Fig. 3. ${ }^{*} \mathrm{Total} \mathrm{Fe}$ as $\mathrm{FeO}$.

\section{Conclusions and the correlation with other mafic and ultramafic rocks in northern Norway}

Evidence of at least 2 major magmatic events can be seen in the area. Tensile stress in the crust made the intrusion of the gabbro sills at Ridnitsohkka feasible. First the tholeiitic magma intruded the fractures thus formed. Then the Raisduoddar-Halti dunite-troctolite-olivine gabbro suite precipitated from a more primitive magma. During the deposition of the cumulates the pressure was low, because the effects of high pressure ( $>5 \mathrm{kbar}$ ) preclude the coexistence of olivine, plagioclase and liquid if the system is rich in $\mathrm{Mg}$ and $\mathrm{Ca}$ (Presnall et al. 1978). During the deposition of the cumulate the tectonic instability continued, and the syngenetic breccias formed. In the last stage, gabbro pegmatoid magma intruded the cumulus rocks as crosscutting dykes. The same magma seeped between the gabbro sill area and the cumulate massif, giving rise to gabbros with augite porphyroblasts.

As shown by the linear change in the composition of the rocks and minerals, the bulk of the
Table 2. Representative microprobe analyses of olivine and orthopyroxene.

\begin{tabular}{|c|c|c|c|c|c|c|}
\hline & 1 & 2 & 3 & 4 & 5 & 6 \\
\hline Sample No.: & 15 & 100 & 37 & 18 & 25 & 87 \\
\hline Location & $\mathrm{R}-\mathrm{H}$ & R-H & $\mathrm{R}-\mathrm{H}$ & $\mathrm{R}-\mathrm{H}$ & $\mathrm{Ri}$ & $\mathrm{Ri}$ \\
\hline $\mathrm{SiO}_{2}$ & 40.9 & 39.7 & 36.4 & 37.0 & 53.2 & 51.4 \\
\hline $\mathrm{Al}_{2} \mathrm{O}_{3}$ & - & - & - & - & - & 0.7 \\
\hline $\mathrm{FeO}$ & 8.9 & 8.2 & 24.2 & 24.8 & 23.6 & 22.5 \\
\hline $\mathrm{MnO}$ & - & - & 0.3 & 0.5 & 0.6 & 0.6 \\
\hline $\mathrm{MgO}$ & 49.5 & 49.5 & 35.3 & 36.9 & 23.1 & 21.5 \\
\hline $\mathrm{CaO}$ & - & - & - & - & 0.2 & 1.6 \\
\hline \multirow[t]{2}{*}{ Total } & 99.3 & 97.4 & 96.2 & 99.2 & 100.7 & 98.3 \\
\hline & \multicolumn{4}{|c|}{ cations per 4 oxygens } & \multicolumn{2}{|c|}{$\begin{array}{l}\text { cations per } 6 \\
\text { oxygens }\end{array}$} \\
\hline $\mathrm{Si}$ & 1.00 & 1.00 & 1.00 & 0.99 & 1.98 & 1.96 \\
\hline $\mathrm{Al}$ & - & - & - & - & - & 0.03 \\
\hline $\mathrm{Fe}$ & 0.18 & 0.17 & 0.55 & 0.55 & 0.73 & 0.72 \\
\hline Mn & - & - & 0.01 & 0.01 & 0.02 & 0.02 \\
\hline $\mathrm{Mg}$ & 1.80 & 1.83 & 1.44 & 1.46 & 1.28 & 1.22 \\
\hline $\mathrm{Ca}$ & - & - & - & - & 0.01 & 0.06 \\
\hline Fo $($ mole $\%)$ & 90.8 & 88.4 & 72.0 & 72.3 & & \\
\hline $\mathrm{mg}$ & & & & & 63.7 & 62.9 \\
\hline
\end{tabular}

1 = olivine in dunite, 2 = olivine in troctolite, 3 = olivine in olivine gabbro, $4=$ olivine in augite augen gabbro, $5=$ orthopyroxene in cpx-ol gabbro sill, $6=$ orthopyroxene in cpx-opx gabbro sill. Location: $\mathrm{R}-\mathrm{H}=$ Raisduoddar-Halti, $\mathrm{Ri}=$ Ridnitsohkka. For additional information on specific sample locations, see Fig. 3. $\mathrm{mg}=100 * \mathrm{Mg} /(\mathrm{Mg}+\mathrm{Fe})$. 
Table 3. Representative microprobe analyses of chrome spinel.

\begin{tabular}{lrrrr}
\hline & 1 & 2 & 3 & \multicolumn{1}{c}{4} \\
\hline Sample No.: & \multicolumn{1}{c}{81} & 15 & 154 & 100 \\
Location & $\mathrm{R}-\mathrm{H}$ & $\mathrm{R}-\mathrm{H}$ & $\mathrm{R}-\mathrm{H}$ & $\mathrm{R}-\mathrm{H}$ \\
$\mathrm{Al}_{2} \mathrm{O}_{3}$ & 34.3 & 30.8 & 31.6 & 26.9 \\
$\mathrm{TiO}_{2}$ & 0.6 & 0.6 & 1.0 & 1.0 \\
$\mathrm{Cr}_{2} \mathrm{O}_{3}$ & 29.2 & 32.2 & 31.7 & 35.5 \\
$\mathrm{Fe}_{2} \mathrm{O}_{3}$ & 4.7 & 4.8 & 5.1 & 3.5 \\
$\mathrm{FeO}$ & 18.4 & 14.7 & 18.5 & 20.1 \\
$\mathrm{MgO}$ & 12.8 & 14.3 & 12.8 & 10.2 \\
$\mathrm{Total}$ & 100.0 & 97.4 & 100.7 & 97.2 \\
& & & & \\
$\mathrm{Al}$ & & cations per & 32 & oxygens \\
$\mathrm{Ti}$ & 9.52 & 8.76 & 8.80 & 7.94 \\
$\mathrm{Cr}$ & 0.10 & 0.11 & 0.18 & 0.18 \\
$\mathrm{Fe}$ & 5.44 & 6.16 & 5.93 & 7.03 \\
$\mathrm{Fe}$ & 0.84 & 0.86 & 0.91 & 0.67 \\
$\mathrm{Mg}$ & 3.62 & 2.94 & 3.67 & 4.36 \\
$\mathrm{Mg} /\left(\mathrm{Mg}+\mathrm{Fe}^{2+}\right)$ & 4.48 & 5.15 & 4.51 & 3.83 \\
$\mathrm{Al} /\left(\mathrm{Al}+\mathrm{Cr}+\mathrm{Fe}^{3+}\right)$ & 0.55 & 0.64 & 0.55 & 0.47 \\
\hline
\end{tabular}

1 and $2=$ chrome spinel in dunite, 3 and $4=$ chrome spinel in troctolite. Location: $\mathrm{R}-\mathrm{H}=$ Raisduoddar-Halti. For additional information on specific sample locations, see Fig. 3.

Table 4. Representative microprobe analyses of plagioclase.

\begin{tabular}{lcccccc}
\hline & 1 & 2 & 3 & 4 & 5 & 6 \\
\hline Sample No. & 100 & 37 & 18 & 45 & 25 & 87 \\
Location & $\mathrm{R}-\mathrm{H}$ & $\mathrm{R}-\mathrm{H}$ & $\mathrm{R}-\mathrm{H}$ & $\mathrm{R}-\mathrm{H}$ & $\mathrm{Ri}$ & $\mathrm{Ri}$ \\
$\mathrm{SiO}_{2}$ & 44.8 & 53.1 & 51.9 & 50.3 & 55.5 & 55.6 \\
$\mathrm{Al}_{2} \mathrm{O}_{3}$ & 32.2 & 29.2 & 30.8 & 31.7 & 28.4 & 26.1 \\
$\mathrm{CaO}$ & 16.2 & 11.1 & 13.5 & 14.8 & 10.7 & 9.2 \\
$\mathrm{Na}_{2} \mathrm{O}$ & 1.9 & 5.3 & 4.2 & 3.4 & 5.9 & 6.0 \\
$\mathrm{~K}_{2} \mathrm{O}$ & - & - & - & - & - & 0.2 \\
$\mathrm{Total}$ & 95.1 & 98.6 & 100.4 & 100.2 & 100.5 & 97.2 \\
& & & & & & \\
$\mathrm{Si}$ & 8.66 & 9.73 & 9.42 & 9.18 & 9.98 & 10.28 \\
$\mathrm{Al}$ & 7.30 & 6.28 & 6.54 & 6.77 & 5.98 & 5.67 \\
$\mathrm{Ca}$ & 3.36 & 2.18 & 2.62 & 2.89 & 2.06 & 1.83 \\
$\mathrm{Na}$ & 0.72 & 1.87 & 1.47 & 1.21 & 2.04 & 2.15 \\
$\mathrm{~K}$ & - & - & - & - & - & 0.05 \\
$\mathrm{An}$ (mole\%) & 82.3 & 53.9 & 64.1 & 70.6 & 50.3 & 46.0 \\
\hline
\end{tabular}

1 = plagioclase in troctolite, 2 = plagioclase in olivine gabbro, 3 = plagioclase in augite augen gabbro, $4=$ plagioclase in amphibole rock, $5=$ plagioclase in cpx-ol gabbro sill, 6 = plagioclase in cpx-opx gabbro sill. Locations: $\mathrm{R}-\mathrm{H}=$ Raisduoddar-Halti, $\mathrm{Ri}=$ Ridnitsohkka. For additional information on specific sample locations, see Fig. 3.
Table 5. Representative microprobe analyses of clinopyroxene and amphibole.

\begin{tabular}{|c|c|c|c|c|c|c|}
\hline & 1 & 2 & 3 & 4 & 5 & 6 \\
\hline Sample No.: & 37 & 18 & 25 & 87 & 45 & 46 \\
\hline Location: & $\mathrm{R}-\mathrm{H}$ & R-H & $\mathrm{Ri}$ & $\mathrm{Ri}$ & $\mathrm{R}-\mathrm{H}$ & R-H \\
\hline $\mathrm{SiO}_{2}$ & 47.2 & 47.5 & 50.1 & 50.5 & 46.5 & 45.3 \\
\hline $\mathrm{TiO}_{2}$ & 2.1 & 2.6 & 0.9 & 0.4 & 0.4 & - \\
\hline $\mathrm{Cr}_{2} \mathrm{O}_{3}$ & 0.2 & 0.3 & - & - & - & - \\
\hline $\mathrm{Al}_{2} \mathrm{O}_{3}$ & 5.4 & 5.2 & 2.6 & 1.3 & 13.8 & 17.1 \\
\hline $\mathrm{FeO}$ & 6.7 & 6.0 & 8.6 & 10.5 & 6.9 & 5.9 \\
\hline $\mathrm{MnO}$ & - & - & 0.3 & 0.4 & - & - \\
\hline $\mathrm{MgO}$ & 13.7 & 13.8 & 14.2 & 14.0 & 15.4 & 14.8 \\
\hline $\mathrm{CaO}$ & 21.6 & 22.8 & 22.1 & 21.4 & 12.7 & 12.5 \\
\hline $\mathrm{Na}_{2} \mathrm{O}$ & 0.8 & 1.0 & - & - & 1.5 & 2.4 \\
\hline \multirow[t]{2}{*}{ Total } & 97.7 & 99.1 & 98.9 & 98.4 & 97.2 & 98.0 \\
\hline & \multicolumn{4}{|c|}{ cations per 6 oxygens } & \multicolumn{2}{|c|}{$\begin{array}{l}\text { cations per } \\
23 \text { oxides }\end{array}$} \\
\hline $\mathrm{Si}$ & 1.80 & 1.79 & 1.90 & 1.93 & 6.62 & 6.37 \\
\hline $\mathrm{Ti}$ & 0.06 & 0.07 & 0.03 & 0.01 & 0.04 & - \\
\hline $\mathrm{Cr}$ & 0.01 & 0.01 & - & - & - & - \\
\hline $\mathrm{Al}$ & 0.24 & 0.23 & 0.12 & 0.06 & 2.31 & 2.83 \\
\hline $\mathrm{Fe}$ & 0.21 & 0.19 & 0.27 & 0.33 & 0.81 & 0.70 \\
\hline $\mathrm{Mn}$ & - & - & 0.01 & 0.01 & - & - \\
\hline $\mathrm{Mg}$ & 0.78 & 0.77 & 0.80 & 0.80 & 3.25 & 3.10 \\
\hline $\mathrm{Ca}$ & 0.88 & 0.92 & 0.90 & 0.88 & 1.94 & 1.88 \\
\hline $\mathrm{Na}$ & 0.06 & 0.07 & - & - & 0.41 & 0.64 \\
\hline En & 41.5 & 41.1 & 40.6 & 39.7 & & \\
\hline Wo & 47.1 & 48.9 & 45.5 & 43.6 & & \\
\hline Fs & 11.4 & 10.0 & 13.9 & 16.7 & & \\
\hline $\mathrm{mg}$ & & & & & 80.0 & 81.6 \\
\hline
\end{tabular}

1 = clinopyroxene in olivine gabbro, 2 = augite augen in augite augen gabbro, 3 = clinopyroxene in cpx-ol gabbro sill, 4 = clinopyroxene in cpx-opx gabbro sill, 5 and $6=$ amphibole in amphibole rock. Location: $\mathrm{R}-\mathrm{H}=$ Raisduoddar-Halti, $\mathrm{Ri}=$ Ridnitsohkka. $\mathrm{mg}=100 * \mathrm{Mg} /(\mathrm{Mg}+\mathrm{Fe})$. For additional information on specific sample locations, see Fig. 3.

cumulate massif crystallized in a closed system. Fractional crystallization can be illustrated with the low-pressure pseudoternary olivine-plagioclase-diopside system. The composition of the parental magma was in the olivine field and shifted via the olivine-plagioclase cotectic to the olivine-plagioclase-clinopyroxene ternary pseudoeutectic, while the dunite, chromitite, troctolite and olivine gabbro were formed by cumulation.

In the Nordreisa area in the north, the uppermost unit of Kalak Nappe Complex contains ultramafites and gabbros with swarms of mafic 
dykes. In terms of stratigraphic position and rock types, the lithologies in the Raisduoddar-Halti and Ridnitsohkka areas correlate well with those rocks which have been dated to $580 \pm 30$ Ma with the $\mathrm{Sm} / \mathrm{Nd}$ method and which have been interpreted as having intruded the rift environment of the Iapetus Ocean (Zwaan and van Roermund 1989).

The igneous rocks of the Seiland Magmatic Province less than $100 \mathrm{~km}$ to the north are generally considered as synorogenic and contemporaneous with the Finnmarkian deformation (Robins and Gardener 1975; Sturt et al. 1978; Bennet et al. 1986). Krill and Zwaan (1987) and Andreasson (1988) have postulated that Seiland igneous rocks intruded the rift environment of the Iapetus Ocean. Roberts (1988) does not entirely reject the rift theory, but favors the concept that the Seiland plutonites are contemporaneous with an episodic. deformation and that they were formed in a transtensional weakness zone at a moderate depth in the crust. In addi-

\section{References}

Andreasson, P.G., 1987. Early evolution of the Late Proterozoic Baltoscandian margin:inferences from rift magmatism. Geol. För. Stockholm Förh. 109, 336-340.

Bennett, M.C., Emblin, S.R., Robins, B. \& Yeo, W.J.A., 1986. High-temperature ultramafic complexes in the North Norwegian Caledonides:I - Regional setting and field relationships. Norges Geol. Unders. 405, 1-40.

Böe, P., 1976. Geology of the troctolite complex of Raisduoddar-Hal'di, Troms, northern Norway. Norges geol. unders. 324, 29-49.

Hausen, H., 1941. Das Halditjokko-Massiv. Ein basischer Phakolith im finnischen Abschnitt der kaledonischen Ueberschiebungszone. Geol. Rundsch. 32, 508-534.

-, 1942. Das Halditjokkomassiv. Ein phacolitischer Intrusionskörper. Basischer differentiate im Abschnitt Finnlands der Kaledoniden. Acta Acad. Aboensis, Mathem. et Phys. XIII. 14, 83 p.

Krill, A.G. \& Zwaan, B., 1987. Reinterpretation of Finnmarkian deformation on western Söröy, northern Norway. Norsk Geol. Tids. 67, 3-13.

Lehtovaara, J.J., 1984. Suomen Kaledonidien rakenteesta. Summary: Features of the structure of the Finnish tion to dunites, the ultramafic cumulates in the Seiland Magmatic Province are composed mainly of olivine clinopyroxenites (Bennett et al. 1986).

A new baddeleyite U-Pb age of $434 \pm 4 \mathrm{Ma}$ (Vaasjoki et al. in prep) shows that the mafic and ultramafic of the Raisduoddar-Halti -Ridnitsohkka area are younger than the Seiland Igneous Province and the rift related rocks in the Nordreisa area. This age is in disagreement with the several earlier lithological correlations in this area, and the mafic and ultramafic rocks of this area can rather be correlated with the synorogenic Scandian mafic intrusive rocks, the largest of them is the Fongen-Hyllingen massif (zircon U$\mathrm{Pb}$ age of $426 \pm 5 \mathrm{Ma}$; Wilson et al. 1983) in the Central Scandinavian Caledonides.

Acknowledgements. I am grateful to Professor H. Papunen who critically read the manuscript and my thanks are due two anonymous referees of this Bulletin. The manuscript was translated into English by Mrs. Gillian Häkli.
Caledonides in the northwesternmost Finnish Lapland. Geologi. 36, 1-9.

-, 1986. Tectonostratigraphical outline of the Finnish Caledonides. Geol. För. Stockholm Förh. 108, 291-294.

-, 1989. Tectonostratigraphic position of the Finnish Caledonides at the Fennoscandian margin of the Northern Scandes. Bull. Geol. Soc. Finland 61, 189-195.

—, \& Sipilä, P., 1987. Revisions to tectonostratigraphy and magmatism of the Finnish Caledonides. Geol. För. Stockholm Förh. 1(19, 354-357.

Presnall, D.C., Dixon, S.A., Dixon, J.R., O'Donell, T.H., Brenner, N.L., Schrock, R.L. \& Dycus, D.W., 1978. Liquidus phase relations on the join diopside-forsteriteanorthite from $1 \mathrm{~atm}$ to $20 \mathrm{kbar}$. Their bearing on the generation and crystallization of basaltic magma. Contrib. Mineral. Petrol. 66, 203-220.

Roberts, D., 1988. Reinterpretation of Finnmarkian deformation on western Söröy, northern Norway: some comments. Norsk Geol. Tids. 68, 309-312.

Robins, B. \& Gardener, P.M., 1975. The magmatic evolution of the Seiland province, and Caledonian plate boundaries in Northern Norway. Earth Planet Sci. Lett. 26, $167-178$. 
Sipilä, P., 1987. Haltitunturin alueen magmakivet. Unpubl. thesis, Dept. Geology, Univ. Turku, 74 p.

-, 1988. Plagioklaasi-oliviinikorona Haltitunturin troktoliitti-oliviinigabrokivissä. In: V.Lappalainen and H. Papunen (eds.), Tutkimuksia geologian alalta (In Finnish). Ann. Univ. Turkuensis, Ser. C, Tom. 67, 31-37.

-, 1989. Mafic and ultramafic rocks of the RaisduoddarHalti area in the Finnish Caledonides - probably a part of the Iapetus rift zone. Terra abs. 1, 7-8.

Sturt, B.A., Pringle, I.R. \& Ramsay, D.M., 1978. The Finnmarkian phase of the Caledonian orogeny. J. geol. Soc. Lond., 135: 547-610.

Vaasjoki, M., Sipilä, P., Lehtovaara, J.J. \& Sakko, M. 1990 (in prep.). U-Pb isotopic determinations on baddeleyite and zircon from the Halti-Ridnitsohkka intrusion in Finnish Lapland: A further constraint on Caledonide evolution.
Wilson, J.R., Hansen, B.T. \& Pedersen, S. 1983. Zircon U$\mathrm{Pb}$ evidence for the age of the Fongen-Hyllingen complex, Trondheim region, Norway. Geol. För. Stockholm Förh. 105, 68-70.

Zwaan, K.B. \& Roberts, D., 1978. Tectonostratigraphic succession and development of the Finnmarkian nappe sequence, North Norway. Norges Geol. Unders. 343, 53-71.

-, K.B. \& van Roermund, H.L.M., 1989. The intrusion mechanism and Caledonian tectono-metamorphic history of a rift-related diabase swarm, preserved in the Corrojavre mega-lens, northern Norway. Terra abs. 1,8 .

Received August 31, 1990

Revision accepted November 13, 1990 